\title{
Improved monitoring of HABs using autonomous underwater vehicles (AUV)
}

\author{
I.C. Robbins , G.J. Kirkpatrick , S.M. Blackwell , J. Hillier , \\ C.A. Knight , M.A. Moline
}

\begin{abstract}
Blooms of toxic algae are increasing in magnitude and frequency around the globe, causing extensive economic and environmental impacts. On the west coast of Florida, blooms of the toxic dinoflagellate Karenia brevis (Davis) have been documented annually for the last 30 years causing respiratory irritation in humans, fish kills, and toxin bioaccumulation in shellfish beds. As a result, methods need to be established to monitor and predict bloom formation and transport to mitigate their harmful effects on the surrounding ecosystems and local communities. In the past, monitoring and mitigation efforts have relied on visual confirmation of water discoloration, fish kills, and laborious cell counts, but recently satellite remote sensing has been used to track harmful algal blooms (HABs) along the Florida coast. Unfortunately satellite ocean color is limited by cloud cover, lack of detection below one optical depth, and revisit frequency, all of which can lead to extended periods without data. To address these shortcomings, an optical phytoplankton discriminator (OPD) was developed to detect K. brevis cells in mixed phytoplankton assemblages. The OPD was integrated into autonomous underwater vehicle (AUV) platforms to gather spatially and temporally relevant data that can be used in collaboration with satellite imagery to provide a 3D picture of bloom dynamics over time. In January 2005, a Remote Environmental Monitoring UnitS (REMUS) AUV with an OPD payload was deployed on the west coast of Florida to retrieve a similarity index (SI), which indicates when $K$. brevis dominates the phytoplankton community. SI was used to monitor a K. brevis bloom in relation to temperature, salinity, chlorophyll, and ocean currents. Current speed, SI, temperature, salinity, and chlorophyll $a$ from the AUV were used to quantify a $1 \mathrm{~km}$ displacement of the K. brevis bloom front that was observed over the deployment period. The ability to monitor short term bloom movement will improve monitoring and predictive efforts that are used to provide warnings for local tourism and fishing industries. In addition, understanding the fine scale environmental conditions associated with bloom formation will increase our ability to predict the location and timing of $K$. brevis bloom formation. This study demonstrates the use of one autonomous platform and provides evidence that a nested array of AUVs and moorings equipped with new sensors, combined with remote sensing, can provide an early warning and monitoring system to reduce the impact of HABs.
\end{abstract}

Keywords: Autonomous underwater vehicles (AUVs); Harmful algal blooms (HABs); Karenia brevis; Optical phytoplankton discriminator (OPD); Similarity index (SI)

\section{Introduction}

The documented increase in harmful algal blooms (HABs) in recent years has stimulated efforts to detect and monitor bloom events (Smayda, 1990; Hallegraeff, 
1993; Anderson, 1995; Tester and Steidinger, 1997; Anderson et al., 2002; Hoagland et al., 2002; Sellner et al., 2003; Islam and Tanaka, 2004). In order to reduce the public health, ecological and economic effects of $\mathrm{HABs}$, a recent national $\mathrm{HAB}$ plan identified the need to predict and track blooms to provide early warning systems for fishing and tourism industries (HARRNESS, 2005). Currently, HAB detection relies on laborious cell counts and costly cruises in response to water discoloration and fish kills. Although effective for bloom detection, these methods lack the potential to rapidly collect temporally and spatially relevant data or provide accurate forecasts of bloom movement (Millie et al., 1997; Schofield et al., 1999).

Remotely sensed ocean color has recently been used to detect and monitor the movement of HABs over large spatial areas (Steidinger and Haddad, 1981; Carder and Steward, 1985; Gower, 1994; Stumpf, 2001; Stumpf et al., 2003; Tang et al., 2004; Tomlinson et al., 2004). Changes in ocean color are a result of in-water constituents (chlorophyll $a$, particulate, and dissolved substances), which possess different absorption and scattering properties (Schofield et al., 1999). These properties allow chlorophyll absorption to be differentiated from other constituents and further separated into different phytoplankton groups, given the presence of distinct optical properties (Cullen et al., 1997; Schofield et al., 1999, 2004). Currently, Trichodesmium (Subramaniam et al., 1999a,b) and Coccolithophore (Brown and Yoder, 1994) blooms can be detected by satellites as a result of their distinct optical properties. Most HABs, however, cannot be tracked remotely until the organism has been identified by cell counts. Additionally, remote sensing is limited by a number of factors: (1) detection is restricted to the near surface and cannot resolve HABs that concentrate below the first optical depth (Stumpf et al., 2003; Tomlinson et al., 2004), (2) sensor detection levels are not sensitive enough at low cell densities (Tester and Stumpf, 1998), (3) clouds interfere with data collection and monitoring, and (4) satellite orbits limit coverage frequency. To overcome these limitations, methods must be developed to optically discriminate between phytoplankton taxa in situ, detect cells at a range of concentrations throughout the water column and be able to track movement over short periods to account for lateral advection and diurnal vertical migration.

In the Gulf of Mexico, fish kills, human health risks, and water discoloration as a result of toxic blooms of Karenia brevis (Davis) have negative impacts on tourism and fishing industries in the region and significantly affect local economies (reviewed by
Kirkpatrick et al., 2004). K. brevis is present throughout the Gulf of Mexico at background concentrations of $<1000$ cells/L, but during bloom events cell concentrations can reach $10^{5}-10^{7}$ cells/L (Dragovich and Kelly, 1966; Tester et al., 1993; Tester and Steidinger, 1997). Since the mid 1980s blooms of K. brevis have been monitored annually along the Florida coast and semiannually along the coasts of Texas and Mexico (Tester and Steidinger, 1997). Blooms frequently occur during the fall months and initiate $18-74 \mathrm{~km}$ offshore on the western continental shelf of Florida. Ocean currents and wind patterns move blooms onshore where they make landfall along the western Florida coast, covering a wide range of ecotones during the bloom cycle (Smayda, 2002).

To reduce the impact of $K$. brevis on local economies and ecosystems, monitoring and prediction methods have been developed by government agencies and academic institutions to enable shellfish farmers and coastal authorities to prepare for shoreward migration of toxic blooms. However, the physiology and ecology of $K$. brevis make it difficult to monitor and accurately predict bloom movement. $K$. brevis is positively phototactic (Steidinger, 1975; Heil, 1986), which can affect remote sensing reflectance as cells move throughout the water column (Schofield et al., 2006). Although cells generally accumulate at the surface during solar noon, this aggregation at subsurface layers has also been documented (Tomlinson et al., 2004). The ability to effectively track blooms requires the ability to optically distinguish toxic cells from general populations in situ at both low and high cell concentrations while gathering ancillary data (temperature, salinity, density, etc.) that can be used in conjunction with remote sensing imagery to detect, track and predict toxic $K$. brevis blooms on four-dimensional scales (space and time).

Millie et al. (1997) demonstrated the differentiation of $K$. brevis from other groups of phytoplankton using stepwise discriminant analysis of converted absorption spectra. Kirkpatrick et al. $(2000,2003)$ refined this process and developed an optical phytoplankton discriminator (OPD; Fig. 1) that detects Karenia spp. in mixed phytoplankton communities in situ. The instrument was modified for moored applications and placed at specific offshore locations for detection in combination with satellite imagery to track blooms as they progress toward land. To address the limitations of remotely sensed data, the OPD was then integrated into autonomous underwater vehicles (AUVs) to retrieve spatial data about bloom dynamics. AUVs allow for deployment at specific sites to gather rapidly sampled, 


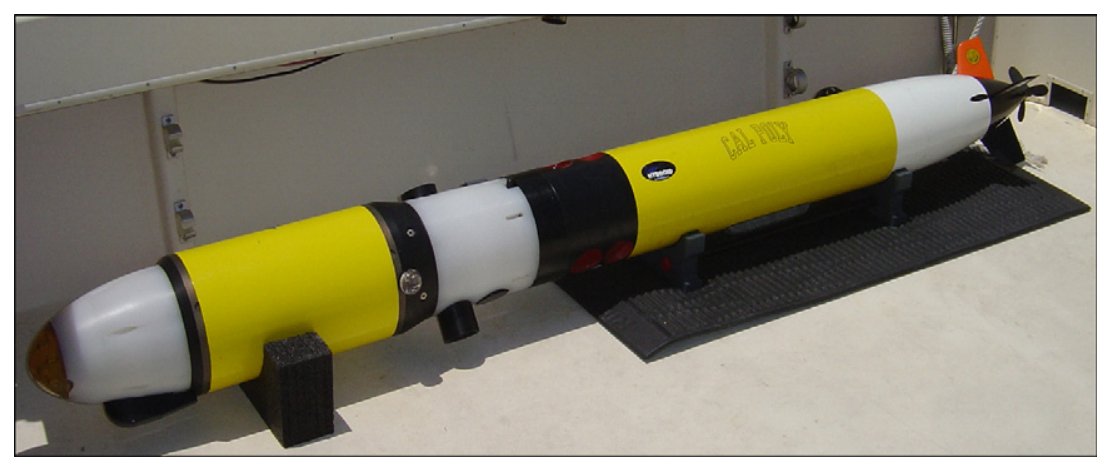

Fig. 1. REMUS AUV ready for deployment in January, 2005 with OPD (forward yellow housing) integrated into the vehicle. Ancillary instrumentation includes a CTD, upward and downward looking ADCPs and fluorometer/backscatter sensor. Total length $\sim 3.0 \mathrm{~m}$.

three-dimensional, near real-time data that is relevant over wide spatial areas. AUVs equipped with the OPD can identify target species while collecting ancillary data that describe the surrounding environmental conditions and provide an improved understanding of the ecology of the HAB species.

The goal of this study was to demonstrate the ability of a Remote Environmental Monitoring UnitS (REMUS) AUV with an OPD payload to map a toxic $K$. brevis bloom and track its movement along the west Florida shelf. This platform was deployed during a toxic bloom of $K$. brevis in January 2005 to examine the relationship between OPD data and temperature, salinity, chlorophyll, cell concentration and ocean currents. This study will also demonstrate the utility and need for a nested array of AUV platforms, moorings, profilers, ships, and satellites to provide early detection and long term tracking of HAB events in the Gulf of Mexico.

\section{Methods}

\subsection{Instrumentation and platforms}

The process of discriminating Karenia spp. from surrounding phytoplankton populations is initiated when the OPD pulls in a sample of whole water using a peristaltic pump that actuates a high pressure syringe system. The water enters a liquid waveguide capillary cell (LWCC, World Precision Instruments Inc.) that is attached to a fiber optic spectrometer (USB2000, Ocean Optics Inc.) and fiber optic tungsten/deuterium light source (D2Lite, World Precision Instruments Inc.). The LWCC serves as a long optical pathlength flowcell, which allows for an increased sensitivity to changes in the absorption of light (Beer's Law). Next, the OPD pulls a sample of water free of colored dissolved organic material (CDOM) from an onboard reservoir to get a reference spectrum. A new raw water sample is filtered through a $0.2 \mu \mathrm{m}$ filter, which removes all particulate so that the absorbance of CDOM can be determined. Finally, the OPD switches valve positions and pushes a nonfiltered water sample into the LWCC and takes the transmitted spectrum. The transmitted spectrum is converted to absorbance and normalized by dividing the absorbance at each wavelength by the mean of the absorbance from 400 to $700 \mathrm{~nm}$. The particle absorbance spectrum does not provide the resolution that is needed to distinguish pigment groups from known standards, so pigment absorbance peaks are transformed using fourth derivative analysis of the normalized absorption spectra (Butler and Hopkins, 1970). This returns a vector of fourth derivatives that is used to determine the angle between the particle absorbance fourth derivative vectors of a standard $K$. brevis sample (culture or monospecific bloom sample) and the unknown natural, mixedpopulation sample (Millie et al., 1995, 1997, 2002; Kirkpatrick et al., 2000,2003). The similarity of the angle is output as the similarity index (SI) between 0 and 1 , with the latter being an exact match to the K. brevis standard and having the strongest correlation with higher concentrations of $K$. brevis.

The OPD has been demonstrated to separate Karenia spp. in the laboratory, but initial cell counts were needed to verify the species composition of the bloom studied here (Kirkpatrick, pers. Comm.). The bloom was identified as $K$. brevis by Mote Marine Laboratory and will be referred to as $K$. brevis from here on when discussing SI.

The REMUS (Fig. 1) is a propulsion-driven AUV that can be easily customized to incorporate different payloads (Moline et al., 2005). In addition to the Ocean Sensors-200 CTD and two $1200 \mathrm{kHz}$ RD Instruments Acoustic Doppler Current Profilers (ADCPs; upward and downward looking), the REMUS was modified to accommodate an OPD (see above), and a Wetlabs Inc. ECO-BBF2 fluorometer/backscatter sensor. 

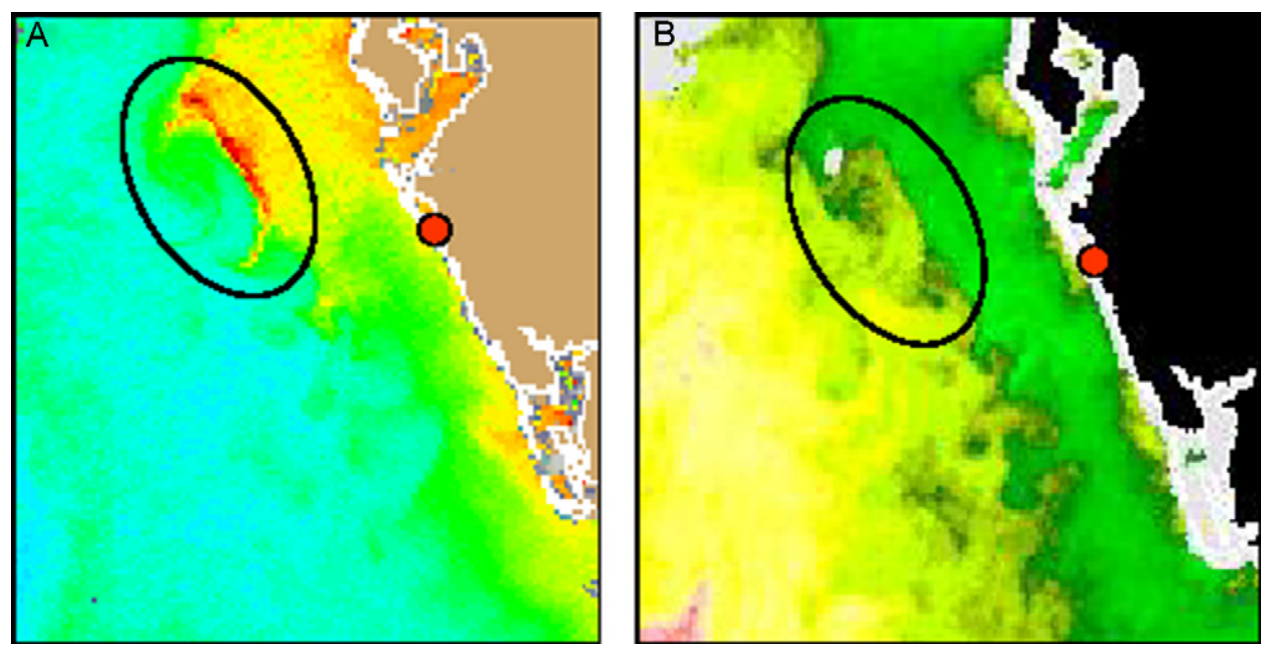

Fig. 2. Moderate resolution imaging spectroradiometer (MODIS) satellite chlorophyll (A) and advanced very high resolution radiometer (AVHRR) sea-surface temperature (B) from January 9, 2005. A high chlorophyll patch along the upwelling front was identified as K. brevis. Warm colors indicate higher values in chlorophyll and temperature. Sarasota, Florida, the site of the study, is indicated by a red filled circle.

\subsection{Mission deployment}

On January 9, 2005, a high chlorophyll concentration was observed using MODIS satellite imagery approximately $50 \mathrm{~km}$ off the west coast of Florida. This bloom was forming along an upwelling front that was confirmed by sea surface temperature satellite imagery (Fig. 2). The bloom was sampled by ships, identified as $K$. brevis and tracked for a month by Mote Marine Laboratory in collaboration with NOAA, the Florida Fish and Wildlife Conservation Commission and the University of South Florida (Fig. 3).

By January 18, 2005 the bloom covered several thousand square kilometers and progressed southeast, where it began making landfall along the central Florida coast. Based on satellite imagery from January 18, the REMUS was programmed to run a $6 \mathrm{~km}$ transect at two depths (1.5 and $4.5 \mathrm{~m}$; Fig. 4) to intersect frontal gradients along the bloom edge. REMUS was deployed at the north end of the transect on January 21, 2005 and navigated to the south end of the transect at $1.5 \mathrm{~m}$, returning to the north end of the transect at $4.5 \mathrm{~m}$. This cycle was repeated twice and lasted $4 \mathrm{~h}$ and $29 \mathrm{~min}$.

The second mission on January 26, 2005 was a box transect that lasted $5 \mathrm{~h}$ and $59 \mathrm{~min}$, with a circumference of $8 \mathrm{~km}$ (Fig. 4). The box was completed at three different depths $(1.5,3$, and $8 \mathrm{~m})$. The REMUS was deployed at the northeast end and traversed the rectangle in a counter clockwise pattern once at each depth. Water samples were collected with a Niskin bottle for cell counts at approximate locations above the REMUS position at three points (north, middle, and south ends of the transect) at 1.5 and $8 \mathrm{~m}$. The OPD was set to sample every 2 min during both missions.

Chlorophyll fluorescence in relation to SI was analyzed with quantile regression analysis using $\mathrm{R}$ statistical software version 2.2.0 (Koenker and Bassett, 1978; Cade and Richards, 1996; Cade et al., 1999; Cade and Guo, 2000; Koenker and Hallock, 2001; Knight and Ackerly, 2002; Cade and Noon, 2003; Knight et al., 2005). Quantile regression is a modified method of least squares regression that estimates linear relationships for
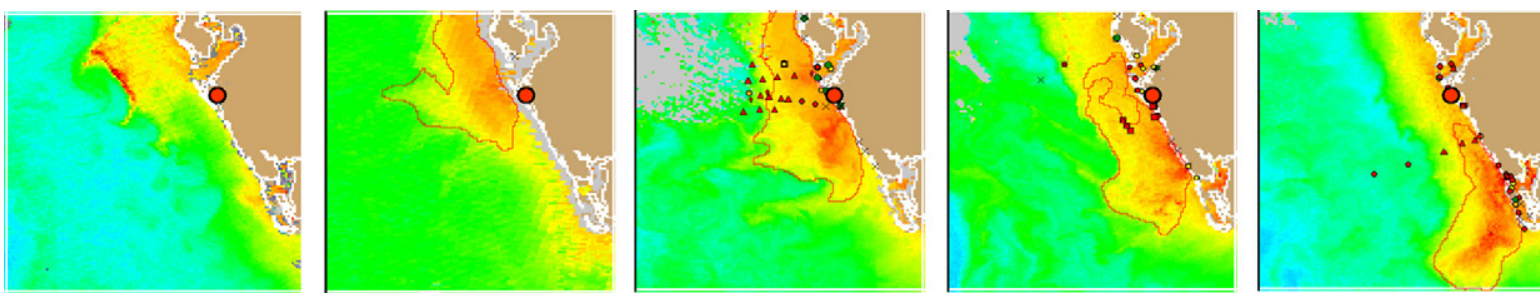

Fig. 3. Same as chlorophyll image in Fig. 2A, but for a month-long time series. Dates for each image from left to right are January 9 , 18, 27, February 10 , and 17 , showing the progression of $K$. brevis southward along the shoreline. Red dot is Sarasota, Florida. Sampling from this study took place between second and third image. 


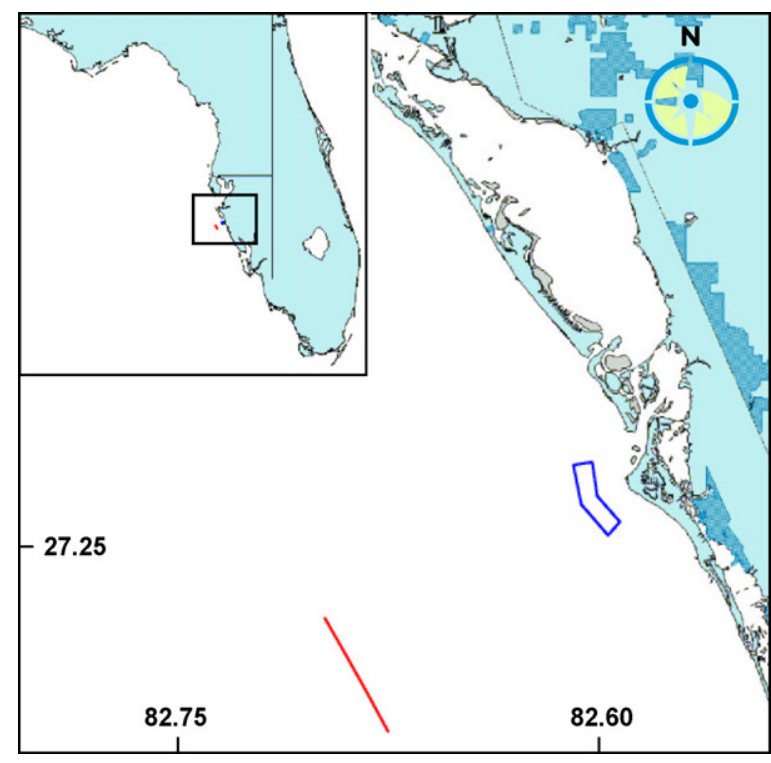

Fig. 4. REMUS transects along the west Florida shelf in January 2005. January 21,2005 was a single transect (blue line), while January 26,2005 was an angled box (red line) further inshore. Starting points for both missions were located in the northwest corner.

a set of quantiles, not just the 50th (as is analogous to the median least squares regression). For the quantile $x$ regression, the dataset is split by the stipulation that $x$ percentage of points fall below the line and $1-x$ percent fall above then line. Then, a best fit line is calculated by minimizing an asymmetrically weighted set of residual errors. Points above the $x$ quantile regression are weighted by $x$ and points falling below the line are weighted by $1-x$. For example, for the 80 th quantile, $80 \%$ of the points fall below the line by definition. The points below the line are weighted by 0.20 and the points above the line are weighted by 0.80 . This method provides a way to analyze the change in slope of the regression estimate for the entire data set to identify if slopes differ from standard regression estimates. Triangular distributions, which are common in ecology, can be quantified with quantile regression by looking at the shape of the $x, y$ plot of quantiles and slopes (Brown and Maurer, 1987; Li, 2002; Knight and Ackerly, 2002). This may provide insight about changing relationships that cannot be analyzed with standard statistical methods.

\section{Results}

The data for the REMUS mission on January 21, 2005 are divided into two parts to demonstrate the utility of REMUS and OPD in monitoring $K$. brevis bloom dynamics. The first half of the mission was from 12:00 to $14: 18$ and the second half was from $14: 19$ to $16: 31$. During the first cycle of the mission, salinity at both depths showed an increase (34-35.8 psu) from north to south along the transect with visible gradients of $0.2 \mathrm{psu}$ (Fig. 5A). Temperature at both depths also increased north to south along the transect $\left(16.0-16.2{ }^{\circ} \mathrm{C}\right)$, but was most apparent near the end of the transect (Fig. 5B). Both salinity and temperature were higher at $4.5 \mathrm{~m}$ relative to the surface depth during the mission. A small, concentrated water mass with higher salinity (37.8 psu) and temperature $\left(17.0^{\circ} \mathrm{C}\right)$ was located at the southern end of the transect at $1.5 \mathrm{~m}$. During the second cycle of the mission, a water mass with the same physical properties was observed $1.5 \mathrm{~km}$ north of the position $2 \mathrm{~h}$ earlier at $1.5 \mathrm{~m}$ (Fig. 5C and D). The northward movement of this water mass was observed along the entire transect. Temperature values at both depths increased during the mission due to solar heating, but the temperature gradients along the transect remained constant.

Current velocities from the REMUS ADCPs indicated there was a mean surface current during the entire mission of $11.60 \mathrm{~cm} / \mathrm{s}$ (std 11.35) in the northwest direction and $7.16 \mathrm{~cm} / \mathrm{s}$ (std 11.16) in the southwest direction with a combined current of $13.63 \mathrm{~cm} / \mathrm{s}$ to the west (Fig. 6). From these measurements, the water mass moved a total of $1.22 \mathrm{~km}$ over the mission.

Chlorophyll values were higher at $1.5 \mathrm{~m}$ (1.5$5.0 \mu \mathrm{g} / \mathrm{L})$ relative to $4.5 \mathrm{~m}(0.5-2.0 \mu \mathrm{g} / \mathrm{L}$; Fig. $7 \mathrm{~A}$ and B) during both cycles of the mission. Chlorophyll concentrations were homogenous throughout the transect except for a high chlorophyll concentration $(>5.0 \mu \mathrm{g} / \mathrm{L})$ located at the southern end of the transect co-located with the high salinity and temperature values. This mass expanded and moved north during the second cycle, mirroring changes in salinity and temperature data. Changes in $K$. brevis SI values mirrored changes in chlorophyll fluorescence (Fig. 8A and B), with significantly higher SI values at $1.5 \mathrm{~m}$ (0.55-0.85) than $4.5 \mathrm{~m}(0.30-0.70)$ for both cycles (ANOVA; $\alpha=.01, R^{2}=40.08, p<0.001$ ). SI values were higher $(>0.70)$ in the northern section of the transect during the first cycle, but during the second cycle high SI values $(>0.70)$ were located in the northern and southern section of the transect.

Samples for $K$. brevis cell counts were not taken at both depths on January 21 . However, cell counts from January 26, 2005 showed higher concentrations of $K$. brevis in the surface layer $(105,000-168,000$ cells/L)

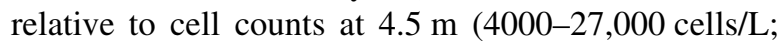
Fig. 9A). Cell counts were significantly correlated with SI values $\left(R^{2}=0.69, p<0.05, n=6\right)$ and correlated with chlorophyll fluorescence (Fig. 9A and B). 

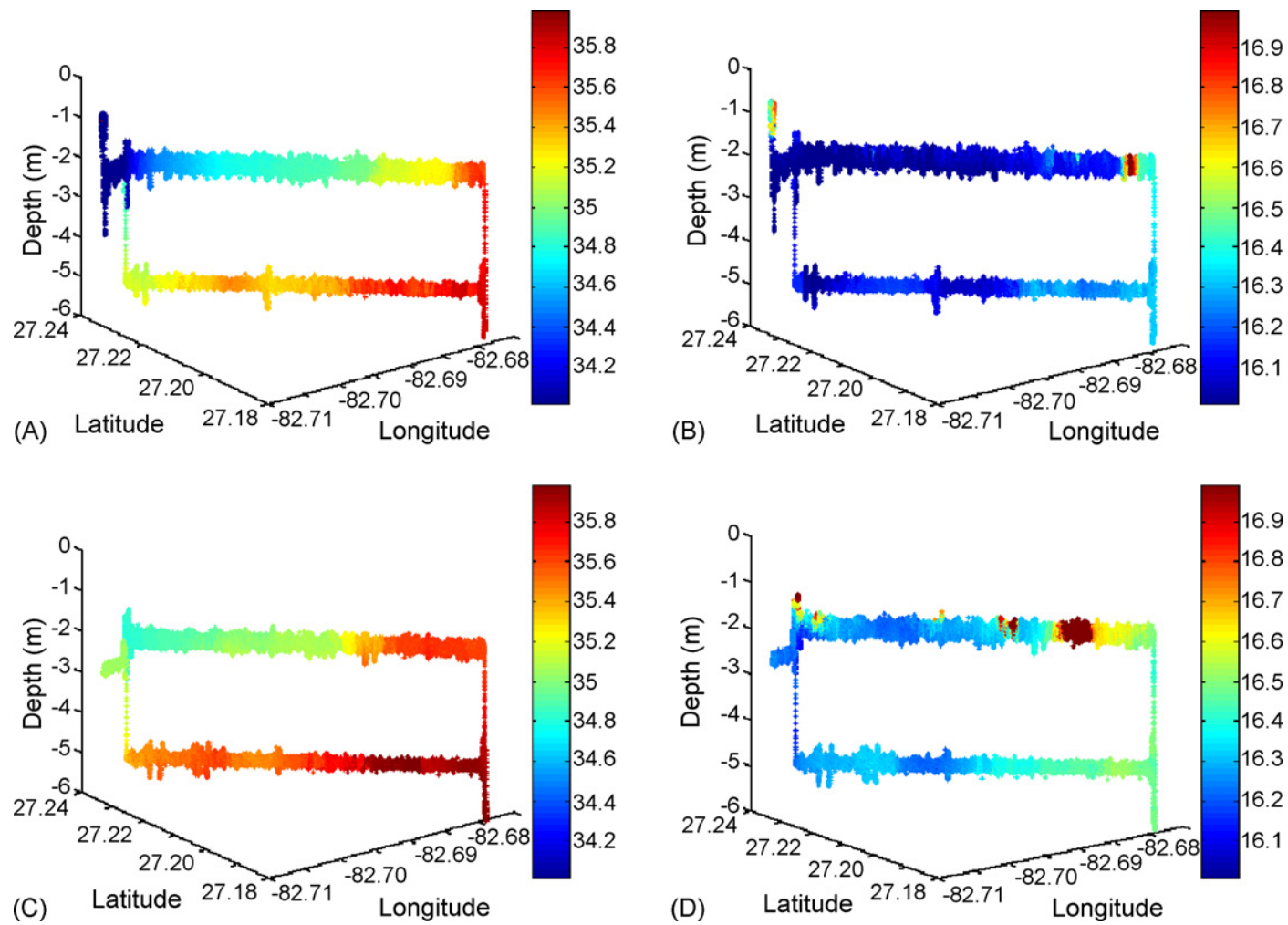

Fig. 5. Salinity (psu; A) and temperature $\left({ }^{\circ} \mathrm{C}\right.$; B) data from the first cycle and salinity (C) and temperature (D) from the second cycle of the January 21, 2005 mission. Left side of graph represents northern most point of the $6 \mathrm{~km}$ transect, where missions started. Viewing angle is from offshore towards land.

SI values from January 21, 2005 were observed across a wide range of salinities $(33.5-35.9 \mathrm{psu})$ and temperatures $\left(15.9-17.7^{\circ} \mathrm{C}\right)$ during both cycles, but concentrations of high SI values $(0.70-0.90)$ shifted in

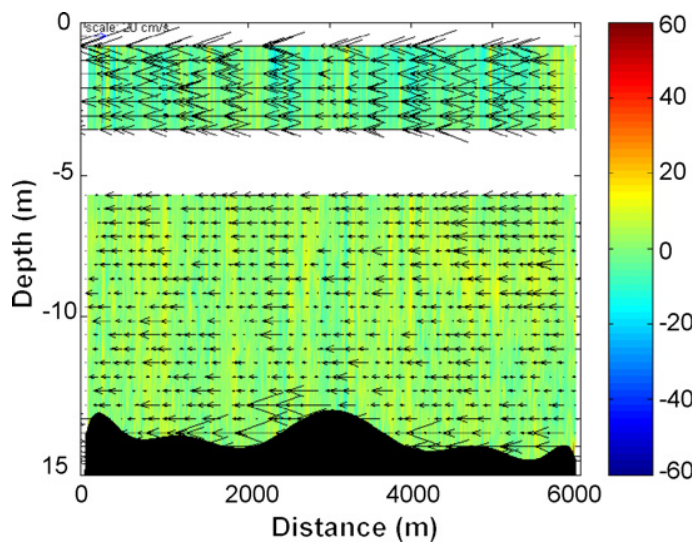

Fig. 6. Representative ADCP current data during second leg of January 21, 2005 REMUS deployment. Arrows represent along shore current movement parallel to the vehicle transect; scale bars at top of figure $=20 \mathrm{~cm} / \mathrm{s}$. Color represents cross shore current movement, with hot colors moving away from the viewer and cool colors moving towards the viewer. REMUS was deployed at left corner of figure. White space around $4.5 \mathrm{~m}$ indicates REMUS path during the mission. temperature/salinity space during the second cycle from $15.9-16.2^{\circ} \mathrm{C}$ and $36.4-36.9$ psu to $16.2-17.6^{\circ} \mathrm{C}$ and 36.8-37.0 psu (Fig. 10A and B). Low SI values were concentrated in the same temperature/salinity space during both cycles, but shifted to warmer and more saline waters during the second cycle.

The relationships between chlorophyll fluorescence and SI for all January 21 data showed that SI had a wide range at low chlorophyll concentrations, but at higher chlorophyll $(>2.5 \mu \mathrm{g} / \mathrm{L})$ concentrations the SI was restricted to high values $(0.55-0.86)$, with only three points below 0.70 (Fig. 11A). Data from January 26 showed similar relationships, but a larger portion of high chlorophyll fluorescence values were correlated with lower SI values (Fig. 11B).

\section{Discussion}

The ability to monitor and track blooms of the toxic dinoflagellate $K$. brevis has improved in recent years as a result of improved technology and a better understanding of the ecology and physiology of the species (Stumpf et al., 2003; Tomlinson et al., 2004). Large scale movement of blooms can be tracked after species 

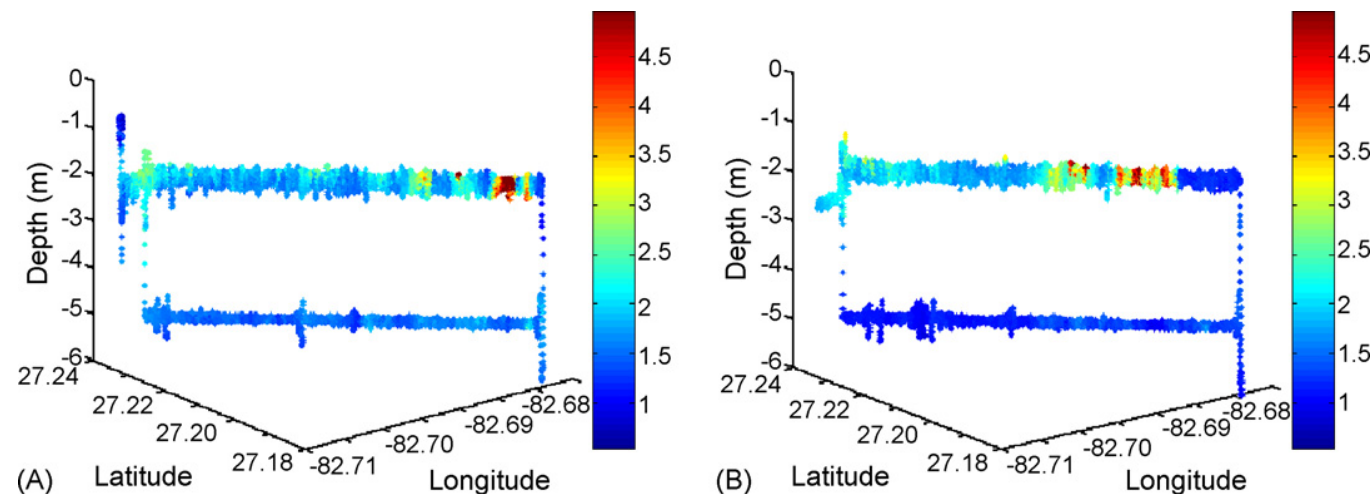

Fig. 7. Chlorophyll fluorescence data ( $\mu \mathrm{g} / \mathrm{L})$ from the first (A) and second (B) cycles of the January 21,2005 mission. Orientation is the same as in Fig. 5.
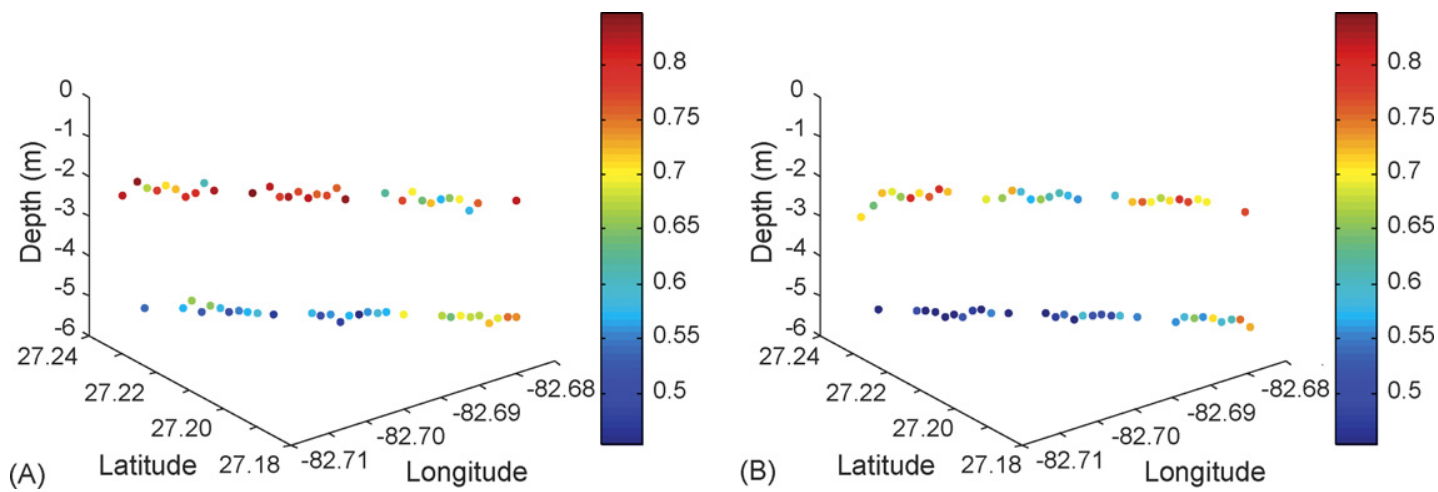

Fig. 8. K. brevis similarity index (SI) from the first (A) and second (B) cycles of the January 21, 2005 mission. Orientation is the same as in Fig. 5.

validation has been completed, but due to sensor/ platform limitations, continuous real time tracking of bloom events is not possible on smaller scales. Small scale dynamics are crucial for predicting the landfall of blooms due to their interaction with inland water outflow, surface currents, lagrangian movement, internal tides, and wind direction. Any of the above factors can cause water masses that contain toxic cells to affect particular areas of coastline, while not affecting other areas only kilometers away. Understanding these dynamics is important for providing accurate predictions that coastal authorities would use to post advisory bulletins to tourists and shellfish harvesters.

The OPD sensor provides a tool to identify when $K$. brevis comprises the majority of phytoplankton
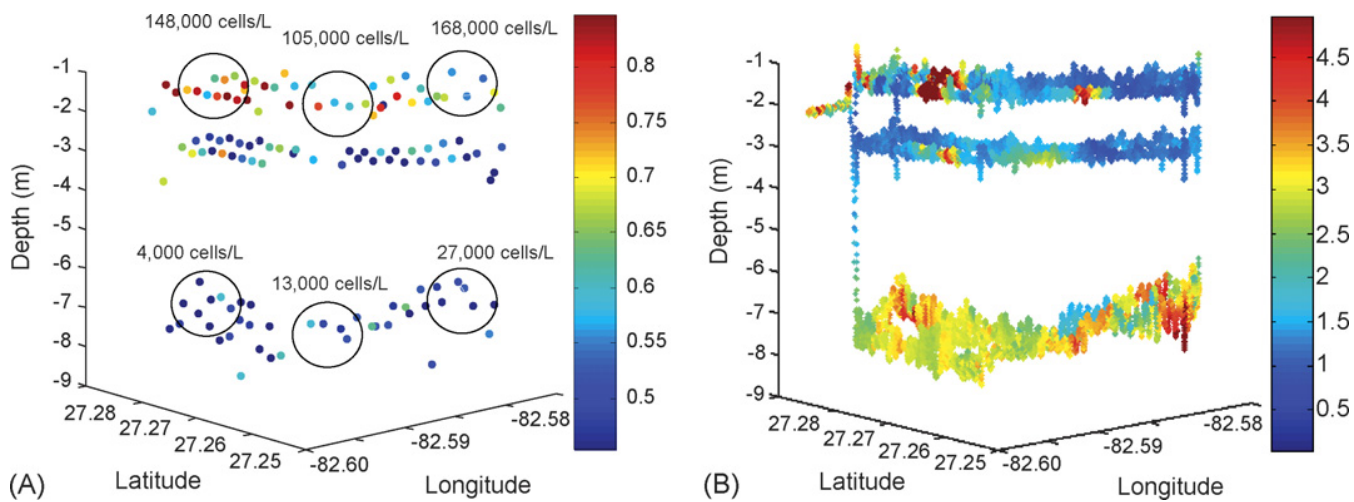

Fig. 9. K. brevis similarity index (SI; A) and chlorophyll fluorescence ( $\mu \mathrm{g} / \mathrm{L} ; \mathrm{B})$ from January 26, 2005 mission. Orientation is the same as in Fig. 5. Transect circumference is $8 \mathrm{~km}$. K. brevis cell counts are indicated with circles for the location where water samples were collected. 

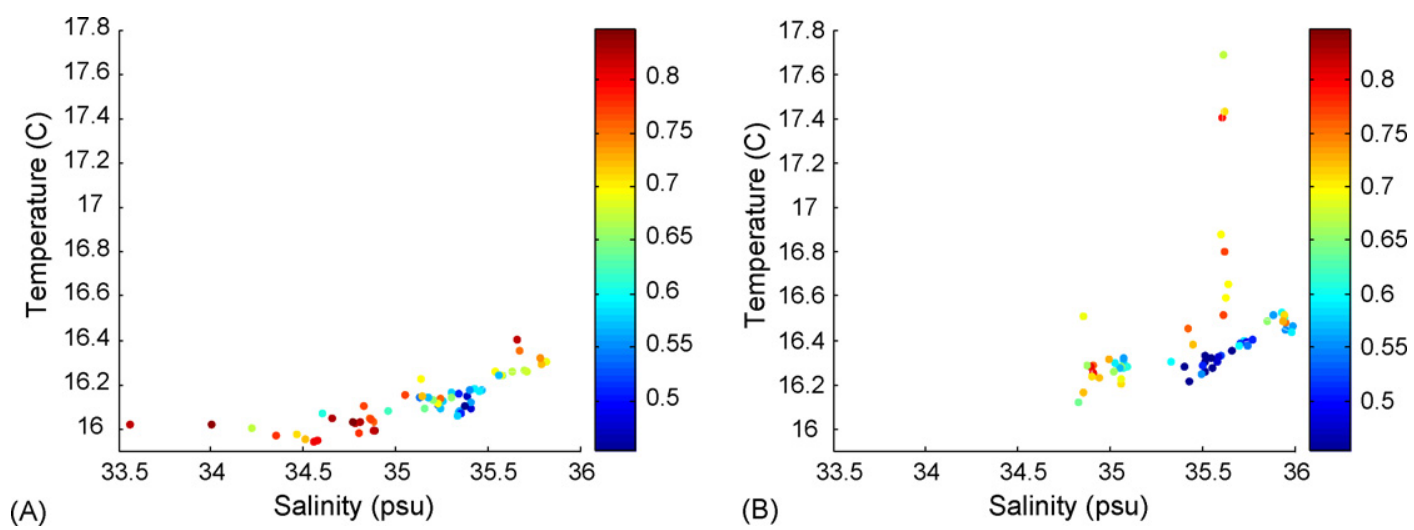

Fig. 10. K. brevis similarity index (SI) in temperature and salinity space for the first (A) and second (B) cycles of REMUS deployment on January 21, 2005. Color bars represent SI values.

biomass, but the ability to characterize bloom movement along fronts within the bloom region is made possible with ancillary data, such as salinity, temperature, current speed/direction, particulate backscatter, and chlorophyll from the AUV platform. The CTD and fluorometer can sample faster than the OPD, which allows for improved resolution of frontal regions present in the coastal ocean. Temperature and salinity gradients drive density gradients and in turn create frontal regions that exhibit forces and impede phytoplankton movement through the water column (Smayda, 2002). These conditions were observed along the transect during this study. Temperature was structured vertically, but generally not along the AUV transect except for the warm water mass at the southern transect boundary (Fig. 5B and D). Salinity showed a consistent gradient, with the highest values at the same region as the warm water mass at $1.5 \mathrm{~m}$ (Fig. 5A and C). A new salinity front moved in from the south carrying warmer more saline water, which advected more $K$. brevis cells into the AUV transect (Figs. 5A, C and 8A, B). This salinity gradient appeared to be the physical mechanism controlling the boundary in this region, as cells were separated along this gradient. As the water mass moved north during the observation period, this boundary and cell concentration relationship remained constant. This northward movement of the water mass was also observed with temperature, chlorophyll, turbidity (data not shown), and SI data.

Surface currents between the different legs, measured by the AUVs ADCP's, showed a mean movement $(13.63 \mathrm{~cm} / \mathrm{s})$ of water in the western direction along the path of the vehicle, or $\sim 1.2 \mathrm{~km}$ over the $2 \mathrm{~h}$ period that
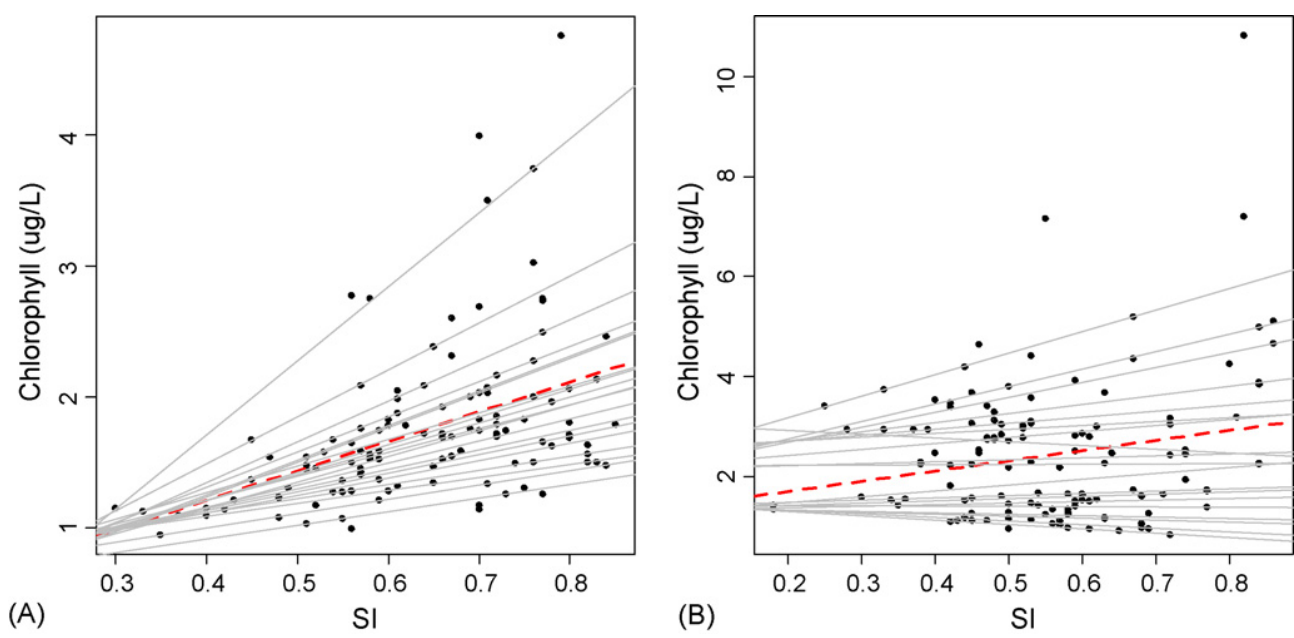

Fig. 11. K. brevis similarity index (SI) vs. chlorophyll fluorescence for the January 21 (A) and January 26 (B), 2005 missions. Grey lines indicate regression line at every fifth quantile. Red dotted line indicates standard linear regression model line. 
elapsed between surface legs. This correlates well with a distance of $1.54 \mathrm{~km}$ measured from the position of the high temperature/salinity front in the southern part of the transect to the position of this front during the third leg of the mission $2 \mathrm{~h}$ later. Differences in these distance estimates suggest that the frontal region was not a linear feature perpendicular to the AUV transect. A non-linear water mass could exhibit movement such as described above. However, because the AUV mission was only one-dimension from an aerial perspective, it was not possible to fully characterize the shape of this front.

The SI was significantly correlated to the cell counts despite the sample locations and the AUV sampling being slightly decoupled in time and space and the previous findings which illustrate that cell concentrations can vary by several factors of 10 due to cell concentration mechanisms (Mackas, 1984). There was a clear separation of $K$. brevis and SI vertically in the water column, with significantly higher concentrations at the surface depths. While the duration of the missions were not long enough to document the vertical movement of cells over the diurnal cycle, this vertical separation of the SI is supportive of previous work on vertical migration in K. brevis (Steidinger, 1975; Heil, 1986; Tester and Steidinger, 1997; Schofield et al., 2006). It is interesting to note that on January 26, the SI was significantly stratified even between 1.5 and $3 \mathrm{~m}$ (Fig. 9A).

The ability to observe cell position in near real-time relative to temperature and salinity also provides a mechanism to examine how cells react to different water masses during migration cycles. Warmer, more saline water was observed at $4.5 \mathrm{~m}$, while cooler, less saline water was observed at the surface, setting up density gradients for migrating $K$. brevis. Three different water masses were characterized during this study. The first water mass was present at $1.5 \mathrm{~m}$ during the first cycle and contained $K$. brevis (Fig. 10A). The second water mass was at $4.5 \mathrm{~m}$ where $K$. brevis was absent during both cycles (Fig. 10A and B), while the third water mass contained new, warm, more saline water in the southern portion of the transect, which contained $K$. brevis cells during the second cycle (Fig. 10B). There were still some cells from the first water mass contained in the second cycle, but there is a clear separation of the two water masses at $1.5 \mathrm{~m}$. An overall shift to warmer water was due to solar warming during the study. This contrast of physical parameters between water masses not only shows the physiological tolerance of $K$. brevis, but also demonstrates the patchiness of phytoplankton blooms (Mackas, 1984). While it is not possible to characterize the migration characteristics of $K$. brevis from this study, the SI in relation to salinity and temperature is higher in more buoyant water masses and is consistent with the migration pattern around solar noon.

The interaction with cell migration and internal waves/fronts has been studied previously (Ryther, 1955; Kamykowski, 1974; Franks, 1997; Lennert-Cody and Franks, 1999, 2002), but research on phytoplankton response to movement across density gradients over broad scales has not been studied. The platform described above provides the ability to examine this relationship in the future. The scenarios described above also demonstrate that this instrument/platform combination can be used to study K. brevis in high and low cell concentrations. While cell concentrations $>50,000$ cells/L can be detected using remote sensors (Tester and Stumpf, 1998; Tomlinson et al., 2004), the OPD/AUV sensor-platform provides a means to study these blooms over a wide range of cell concentrations $\left(10^{4-6}\right.$ cells/L) below the surface, making it possible to identify species composition and track blooms prior to satellite detection (Kirkpatrick et al., 2000).

While optical discrimination of $K$. brevis in mixed assemblages has been demonstrated previously in the laboratory (Millie et al., 1995, 1997, 2002) and in natural environments (Kirkpatrick et al., 2000), prior to this study these optical techniques have not been tested spatially in heterogeneous environments. To effectively monitor and track blooms of $K$. brevis, the OPD must identify boundaries where $K$. brevis is the dominant organism in the community, represented by elevated SI and chlorophyll, as opposed to depressed SI and elevated chlorophyll where $K$. brevis is a minor contributor to biomass. SI is directly related to the percentage of biomass contributed by $K$. brevis and is considered to be significant when SI outputs are greater than 0.70 (Kirkpatrick et al., 2000). High SI values would indicate that $K$. brevis is the dominant organism in the community and is present in both low cell numbers and low chlorophyll $\left(10^{4}-10^{5} / \mathrm{L}, 1-3 \mu \mathrm{g} / \mathrm{L}\right)$ or high cell numbers and high chlorophyll $\left(10^{6} / \mathrm{L},>3 \mu \mathrm{g} /\right.$ L), which are represented on both days (Fig. 11A and B). Chlorophyll and SI values from January 21 show that cells were present at $1.5 \mathrm{~m}$, but not at $4.5 \mathrm{~m}$, signifying that all of the high SI values were at $1.5 \mathrm{~m}$ (Figs. 8A, B and 9A). Cell concentrations varied significantly in the surface layer and would cause chlorophyll values to fluctuate, but not SI, which accounts for lower chlorophyll at high SI (Fig. 11A). Additionally, low SI values were located at $4.5 \mathrm{~m}$ where $K$. brevis was either not present or their signal was masked by other species that made up more of the 

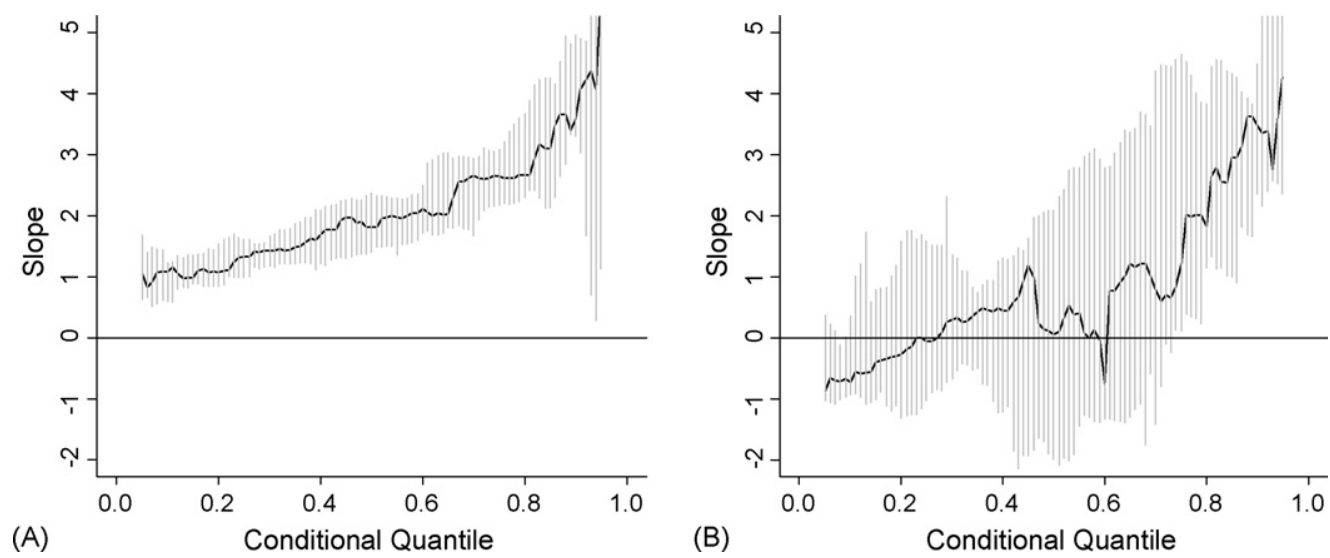

Fig. 12. Mean (black) and error (grey) of the slope of the quantile regressions for the K. brevis similarity index (SI) vs. chlorophyll fluorescence relationships in Fig. 11 for the January 21 (A) and January 26 (B), 2005 missions.

biomass at that depth. As a result we can assume that within the bloom boundaries this event was monospecific.

Similarity Index/chlorophyll data from January 26 exhibits a similar triangular pattern, but more data points are associated with lower SI values and higher chlorophyll values (Fig. 11B). Elevated chlorophyll concentrations are located at all depths, but high SI values are only located at $1.5 \mathrm{~m}$ indicating that $K$. brevis is only located at the surface (Fig. 9A and B). These relationships suggest that the phytoplankton community consisted of species other than K. brevis in relationship to overall cell biomass, which was in fact confirmed with cell counts (data not shown). The location of the mission on January 26 was in the coastal environment and in close proximity to Big Sarasota Pass and the outflow of Sarasota Bay (Fig. 4). The contribution of other phytoplankton that routinely bloom in these bays from enhanced nutrient sources (Smayda, 1990; Anderson, 1995; Tester and Steidinger, 1997; Anderson et al., 2002; Islam and Tanaka, 2004) may have increased the observed species heterogeneity.

Data from this study suggests that the combination of SI and chlorophyll fluorescence may be used as an indicator of monospecificity in high chlorophyll waters. As chlorophyll decreases the contribution of any one species decreases so that the SI index spans a proportionally larger range. This is consistent with the increasing diversity with decreasing cell concentrations in natural communities (Hutchinson, 1961; Gilmartin and Revelante, 1974; Titman, 1976; Tilman, 1977) and leads to a triangular distribution of data in SI/ chl space (Fig. 11A). There is a lack of observations in the high chlorophyll and low SI quadrant, which would indicate a phytoplankton bloom other than K. brevis. Attempting to use traditional linear regression models with these data distributions is problematic and does not quantitatively represent their distributions or encapsulate the meaningful information that can be gleaned from them. Quantile regression may be a viable tool to identify bloom composition by examining the changing relationships between chlorophyll fluorescence and SI. Fig. 12A and B shows a quantile regression analysis of chlorophyll and SI for January 21 and 26, highlighting the differences between the relationships from each day. Qualitatively, the difference between the relationships from January 21 and 26 are only statistically different at particular quantiles (5th-40th), however, this method may provide a graphical tool to determine bloom composition. Quantile regression provides a metric that can be used to further explore these relationships in other phytoplankton species. By comparing vectors of absorption values across the visible light spectrum, the OPD may detect changes that result from ecological niches as opposed to individual pigment differences between species, making it possible to study other species. Future deployments will be needed to explore the potential of this tool in investigating the relationship that phytoplankton groups have during bloom cycles in the Gulf of Mexico.

\section{Conclusion}

The ability of the REMUS and OPD to discriminate $K$. brevis from mixed communities and track bloom movement over small spatial scales was successfully demonstrated. Future work with the OPD and AUVs will need to address several different aspects of phytoplankton bloom dynamics. The first is the need to observe bloom events over extended periods of time during the day, and for consecutive days/weeks during the entire bloom event. Although the utility of the OPD 
to map $K$. brevis blooms was demonstrated above, the success of these instruments will be dependent on further integration into platforms, a larger distribution and routine deployments of sensors in the Gulf of Mexico. Initial efforts to study HABs and environmental variables with multi-platform networks have successfully shown the need for further implementation and verification (Steidinger and Haddad, 1981; Carder and Steward, 1985; Gower, 1994; Stumpf, 2001; Walsh et al., 2002; Stumpf et al., 2003; Tang et al., 2004; Tomlinson et al., 2004). This potential has been alluded to for years, but the availability of smaller and more reliable technology has only recently made this possible (Cullen et al., 1997; Schofield et al., 1999, 2002). Successful detection and monitoring of $K$. brevis in mixed assemblages using the OPD has been demonstrated by Kirkpatrick et al. (2000; pers. comm.) on several occasions using moorings and now AUVs (REMUS and Slocum gliders; Schofield et al., 2002). Currently, these instruments are being integrated into NOAA HAB monitoring programs in Florida (Walsh et al., 2002; Stumpf et al., 2003; Tomlinson et al., 2004), providing advanced warning of shoreward moving blooms.

Although OPD payloads have been used to detect red tides on the west coast of Florida in the past, the ability to study blooms of $K$. brevis on small scales in conjunction with multiple parameters of the surrounding water column have not been shown prior to this study. The combination of instruments demonstrated here is essential to accurately access blooms of $K$. brevis due to cell concentration mechanisms and heterogeneous distribution throughout the water column. Prediction and monitoring methods must account for these physical and biological mechanisms as bloom dynamics change rapidly over short time scales.

To address these requirements, an integrated network of platforms/sensors would be needed throughout the Gulf of Mexico to detect subsurface populations and bloom initiation events. Based on tested systems currently available, this network would consist of an array of mobile (AUVs) and fixed (moorings) assets. Once the gliders/moorings had detected a bloom, REMUS and other shipboard payloads could be nested within the sample region on short notice to systematically map dynamics on smaller scales, study the environmental parameters that support bloom development and senescence, and refine algorithms that are used to characterize blooms using remote sensing. This nested multiplatform network would provide near-real time status of $K$. brevis blooms on a year-round basis in an effort to reduce the health, economic and environmental impacts.

\section{Acknowledgements}

A special thanks to Shelley Blackwell, Michael Sauer, Jessica Connolly, Jason Morgan, Jeff Sevajian, Tom Moylan, Barbara Kirkpatrick, Cory Boyes, Jim Hillier, Brad Pederson, Dana Dalpra, and my beloved wife Amy. In addition I would like to thank Mote Marine Laboratory and everybody in the Biological Sciences Department at Cal Poly for all that I have learned in my residence at both facilities. This paper is a result of research funded by the National Oceanic and Atmospheric Administration Coastal Ocean Program under award NA16OP2955 (M.A.M., G.J.K.), by the National Science Foundation under award DBI-0138036 (M.A.M., G.J.K.), by the Florida Fish and Wildlife Conservation Commission award 04089 (G.J.K.), and by National Aeronautics and Space Administration under award NAG 5-8674 (M.A.M.). [SES]

\section{References}

Anderson, D.M., 1995. Toxic red tides and harmful algal blooms: a practical challenge in coastal oceanography. Rev. Geophys. 33 (Supplement), 1189-1200.

Anderson, D.M., Glibert, P.M., Burkholder, J.M., 2002. Harmful algal blooms and eutrophication: nutrient sources, composition, and consequences. Estuaries 25 (4b), 704-726.

Brown, C.W., Yoder, J.A., 1994. Coccolithoporid blooms in the global ocean. J. Geophys. Res. 99 (C4), 7476-7482.

Brown, J.H., Maurer, B.A., 1987. Evolution of species assemblages: effects of energetic constraints and species dynamics on the diversification of the North American avifauna. Am. Nat. 130, 1-17.

Butler, W.L., Hopkins, D.W., 1970. An analysis of fourth derivative spectra. Photochem. Photobiol. 12, 451-456.

Cade, B.S., Richards, J.D., 1996. Permutation test for least absolute deviation regression. Biometrics 52, 886-902.

Cade, B.S., Terrell, J.W., Schroeder, R.L., 1999. Estimating effects of limiting factors with regression quantiles. Ecology 80, 311-323.

Cade, B.S., Guo, Q., 2000. Estimating effects of constraints on plant performance with regression quantiles. Oikios 91, 245-254.

Cade, B.S., Noon, B.R., 2003. A gentile introduction to quantile regression for ecologists. Front. Ecol. Environ. 1, 412-420.

Carder, K.L., Steward, R.G., 1985. Remote-sensing reflectance model of a red-tide dinoflagellate off west Florida. Limnol. Oceanogr. 30, 286-298.

Cullen, J.J., Ciotti, A.M., Davis, R.F., Lewis, M.R., 1997. Optical detection and assessment of algal blooms. Limnol. Oceanogr. 42, 1223-1239.

Dragovich, A., Kelly, J.A., Jr., 1966. Distribution and occurrence of Gymnodinium breve on the west coast of Florida, 1964-65. U.S. Fish Wildl. Serv. Spec. Sci. Rep. Fish. 15 p.

Franks, P.J.S., 1997. Spatial patterns in dense algal blooms. Limnol. Oceanogr. 42, 1297-1305.

Gilmartin, M., Revelante, N., 1974. The 'island mass' effect on the phytoplankton and primary production of the Hawaiian Islands. J. Exp. Mar. Biol. Ecol. 16, 181-204.

Gower, J.F.R., 1994. Red tide monitoring using AVHRR HRPT imagery from a local receiver. Rem. Sens. Environ. 48, 309-318. 
Hallegraeff, G.M., 1993. A review of harmful algal blooms and their apparent global increase. Phycologia 32, 79-99.

HARRNESS, 2005. Harmful algal research and response: a national environmental science strategy 2005-5015, in: Ramsdell, J.S., Anderson, D.M., Glibert, P.M. (Eds.), Ecol. Soc. Am., Washington, DC, $96 \mathrm{pp}$.

Heil, C.A., 1986. Vertical migration of Ptychodiscus brevis (Davis) Steidinger. M.Sc. Thesis, University of South Florida, St. Petersburg, FL.

Hoagland, P., Anderson, D.M., Kaoru, Y., White, A.W., 2002. The economic effects of harmful algal blooms in the United States: estimates, assessment issues, and information needs. Estuaries 25, 819-837.

Hutchinson, G.E., 1961. The paradox of the plankton. Am. Nat. 95, 137-140.

Islam, M.S., Tanaka, M., 2004. Impacts of pollution on coastal and marine ecosystems including coastal and marine fisheries and approach for management: a review and synthesis. Mar. Pollut. Bull. 48, 624-649.

Kamykowski, D., 1974. Possible interactions between phytoplankton and semidiurnal internal tides. J. Mar. Res. 32, 67-89.

Kirkpatrick, B., Fleming, L.E., Squicciarini, D., Backer, D., Clark, R., Abraham, W., Benson, J., Cheng, Y.S., Johnson, D., Pierce, R., Zaias, J., Bossart, G.D., Baden, D.G., 2004. Literature review of Florida red tide: implications for human health effects. Harmful Algae 3, 99-115.

Kirkpatrick, G.J., Millie, D.F., Moline, M.A., Schofield, O.M., 2000. Optical discrimination of a phytoplankton species in natural mixed populations. Limnol. Oceanogr. 45 (2), 467-471.

Kirkpatrick, G.J., Orrico, C., Moline, M.A., Oliver, M., Schofield, O.M., 2003. Continuous hyperspectral absorption measurements of colored dissolved organic material in aquatic systems. Appl. Opt. 42 (33), 6564-6568.

Knight, C.A., Ackerly, D.D., 2002. Variation in nuclear DNA content across environmental gradients: a quantile regression analysis. Ecol. Lett. 5, 66-76.

Knight, C.A., Molinari, N.A., Petrov, D.A., 2005. The large genome constraint hypothesis: evolution, ecology, and phenotype. Ann. Bot. 95, 177-190.

Koenker, R., Bassett, G., 1978. Regression analysis. Econometrica 46, $33-50$.

Koenker, R., Hallock, K.F., 2001. Quantile regression: an introduction. J. Econ. Pers. 15, 143-156.

Lennert-Cody, C.E., Franks, P.J.S., 1999. Plankton patchiness in highfrequency internal waves. Mar. Ecol. Prog. Ser. 186, 59-66.

Lennert-Cody, C.E., Franks, P.J.S., 2002. Fluorescence patches in high-frequency internal waves. Mar. Ecol. Prog. Ser. 235, 29-42.

Li, W.K.W., 2002. Macroecological patterns of phytoplankton in the northwestern North Atlantic Ocean. Nature 419, 154-157.

Mackas, D.L., 1984. Spatial autocorrelation of plankton community composition in a continental shelf ecosystem. Limnol. Oceanogr. 29, 451-471.

Millie, D.F., Kirkpatrick, G.J., Vinyard, B.T., 1995. Relating photosynthetic pigments and in vivo optical density spectra to irradiance for the Florida red-tide dinoflagellate Gymnodinium breve. Mar. Ecol. Prog. Ser. 120, 65-75.

Millie, D.F., Moline, M.A., Schofield, O., 1997. Optical discrimination of a phytoplankton species in natural mixed populations. Limnol. Oceanogr. 45 (2), 467-471.

Millie, D.F., Schofield, O., Kirkpatrick, G.J., Johnsen, G., Evens, T.J., 2002. Using absorbance and fluorescence spectra to discriminate microalgae. Eur. J. Phycol. 37, 313-322.
Moline, M.A., Blackwell, S.M., Allen, B., Austin, T., Forrester, N., Goldsborogh, R., Purcell, M., Stokey, R., von Alt, C., 2005. Remote environmental monitoring units: an autonomous vehicle for characterizing coastal environments. J. Atmos. Ocean. Technol. 22 (11), 1798-1809.

Ryther, J.H., 1955. Ecology of autotrophic marine dinoflagellates with reference to red water conditions, in: Johnson, F.H. (Ed.), The luminescence of biological systems. Am. Assoc. Adv. Sci., New York, pp. 387-413.

Schofield, O., Grzymski, J., Bissett, W.P., Kirkpatrick, G.J., Millie, D.F., Moline, M., Roesler, C.S., 1999. Optical monitoring and forecasting systems for harmful algal blooms: possibility or pipe dream. J. Phycol. 35, 1477-1496.

Schofield, O., Bergmann, T., Bissett, W.P., Grassle, F., Haidvogel, D. Kohut, J., Moline, M.A., Glenn, S., 2002. The long-term ecosystem observatory: an integrated coastal observatory. J. Ocean. Eng. 27, 146-154.

Schofield, O., Bergmann, T., Bissett, W.P., Moline, M.A., Orrico, C., 2004. Inverting inherent optical signatures in the near shore coastal waters at the long term ecosystem observatory. J. Geophys. Res. 109, C12S04, doi:10.1029/2003JC002071.

Schofield, O., Kerfoot, J., Mahoney, K., Moline, M.A., Oliver, M., Lorenz, S., Kirkpatrick, G., 2006. Vertical migration of the toxic dinoflagellate Karenia brevis and the impact on ocean optical properties. J. Geophys. Res. 111, C06009, doi:10.1029/2005JC003115.

Sellner, K.G., Doucette, G.J., Kirkpatrick, G.J., 2003. Harmful algal blooms: causes, impacts and detection. J. Ind. Microbiol. Biotechnol. 30, 383-406.

Smayda, T.J., 1990. Novel and nuisance phytoplankton blooms in the sea: evidence for a global epidemic. In: Granelij, E., Sundstrom, B., Edler, L., Anderson, D.M. (Eds.), Toxic Marine Phytoplankton. Elsevier, New York.

Smayda, T.J., 2002. Turbulence, watermass stratification and harmful algal blooms: an alternative view and frontal zones as "pelagic seed banks". Harmful Algae 1, 95-112.

Steidinger, K.A., 1975. Basic factors influencing red tides. In: Proceedings of the First Conference on Toxic Dinoflagellate Blooms. Mass. Sci. Technol. Found.

Steidinger, K.A., Haddad, K., 1981. Biologic and hydrographic aspects of red tides. BioScience 31 (11), 814-819.

Stumpf, R.P., 2001. Applications of satellite ocean color sensors for monitoring and predicting harmful algal blooms. Hum. Ecol. Risk Assess. 7 (5), 1363-1368.

Stumpf, R.P., Culver, M.E., Tester, P.A., Tomlinson, M., Kirkpatrick, G.J., Pederson, B.A., Truby, E., Ransibrahmanakul, V., Soracco, M., 2003. Monitoring Karenia brevis blooms in the Gulf of Mexico using satellite ocean color imagery and other data. Harmful Algae 2, 147-160.

Subramaniam, A., Carpenter, E.J., Falkowski, P.G., 1999a. Bio-optical properties of the marine diazotrophic cyanobacteria Trichodesmium spp.: II. A reflectance model for remote sensing. Limnol. Oceanogr. 44 (3), 618-627.

Subramaniam, A., Carpenter, E.J., Karentz, D., Falkowski, P.G., 1999b. Bio-optical properties of the marine diazotrophic cyanobacteria Trichodesmium spp.: I. Absorption and photosynthetic action spectra. Limnol. Oceanogr. 44 (3), 618-627.

Tang, D.L., Kawamura, H., Doan-Nhu, H., Takahashi, W., 2004. Remote sensing oceanography of a harmful algal bloom off the coast of southeastern Vietnam. J. Geophys. Res. 109, C030114.

Tester, P.A., Geesey, M.E., Vukovich, F.M., 1993. Gymnodinium breve and global warming: What are the possibilities? In: Toxic phytoplankton blooms in the sea. Proceedings of the 5th International 
Conference On Toxic Phytoplankton. Elsevier, New York, pp. 76-82.

Tester, P.A., Steidinger, K.A., 1997. Gymnodinium breve red tide blooms: initiation, transport, and consequences of surface circulation. Limnol. Oceanogr. 42 (5 part 2), 1039-1051.

Tester, P.A., Stumpf, R.P., 1998. Phytoplankton blooms and remote sensing: what is the potential for early warning. J. Shellfish Res. 17 (5), 1469-1471.

Titman, D., 1976. Ecological competition between algae: experimental confirmation of resource-based competition theory. Science 192, 463-464.
Tilman, D., 1977. Resource competition between plankton algae: an experiment and theoretical approach. Ecology 58, 338-348.

Tomlinson, M.C., Stumpf, R.P., Ransibrahmanakul, V., Truby, E.W., Kirkpatrick, G.J., Pederson, B.A., Vargo, G.A., Heil, C.A., 2004. Evaluation of the use of SeaWiFS imager for detecting Karenia brevis harmful algal blooms in the eastern Gulf of Mexico. Rem. Sens. Environ. 91, 293-303.

Walsh, J.J., Dieterle, D.A., Milroy, S.P., Jolliff, J.K., Darrow, B.P., Lenes, J.M., Weisberg, R.H., He, R., 2002. Three-dimensional biophysical models of Florida red tides. Abstract, 10th International Conference on Harmful Algae, St. Pete Beach, FL. 